\section{Miljana Pavićević ${ }^{1}$}

Katedra za

psihologiju, Filozofski

fakultet Kosovska

Mitrovica, Univerzitet

u Prištini

\section{Snežana \\ Stojijković}

\section{Departman za}

psihologiju, Filozofski fakultet, Univerzitet u Nišu
1 Adresa autora:

miljanapavicevic@yahoo.com.

Primljeno: 04. 07. 2015.

Primljena korekcija:

10. 11. 2015.

Prihvaćeno za štampu:

13. 12. 2015.
PERCIPIRANI VASPITNI STAVOVI RODITELJA KAO PREDIKTORI INTERPERSONALNE ORIJENTACIJE STUDENATA ${ }^{2}$

Istraživanja pokazuju da vaspitni postupci roditelja doprinose formiranju različitih osobina ličnosti i interpersonalnih relacija koje deca uspostavljaju tokom razvoja. Cilj rada je bio da se ispita kakva je prediktivna moć vaspitnih stavova roditelja u predviđanju interpersonalne orijentacije studenata, tačnije, pojedinih aspekata filantropske i mizantropske orijentacije. Istraživanjem je obuhvaćeno 238 studenata oba pola različitih fakulteta Univerziteta u Prištini, prosečne starosti 21.61. Za prikupljanje podataka korišćeni su Skala za procenu vaspitnih stavova roditelja VS i Skala interpersonalne orijentacije IO. VS skala meri dve dimenzije vaspitanja, afektivnu (polovi toplo-hladno vaspitanje) i dimenziju kontrole (polovi popustljivo-ograničavajuće vaspitanje). Rezultati multiple regresione analize pokazuju da je percipirano toplo vaspitanje majke značajan prediktor prijateljstva, aspekta filantropske orijentacije, i socijalne izolacije (sa negativnim predznakom), aspekta mizantropske orijentacije. Hladno vaspitanje majke je značajan prediktor nepoverenja, aspekta mizantropske orijentacije, dok je ograničavajuće vaspitanje majke značajan prediktor potrebe za ljudima i prijateljstva, aspekata filantropske orijentacije. Vaspitni stavovi oca se nisu pokazali značajnim u predviđanju interpersonalne orijentacije studenata. Generalno gledano, percipirani vaspitni stil majke važniji je nego vaspitni stil oca za objašnjenje interpersonalne orijentacije osobe, a pritom je veći doprinos afektivne dimenzije vaspitanja nego dimenzije kontrole. Nalazi se diskutuju iz ugla raspoložive empirijske evidencije u ovoj oblasti psihologije i ukazuje na pravac budućih istraživanja.

Ključne reči: vaspitni stavovi roditelja, interpersonalna orijentacija, filantropska orijentacija, mizantropska orijentacija, studenti

\footnotetext{
2 Rad je nastao u okviru projekta „Indikatori i modeli usklađivanja profesionalnih i porodičnih uloga”, br. 179002, koji finansira Ministarstvo prosvete, nauke i tehnološkog razvoja Republike Srbije.
} 


\section{Vaspitni stavovi roditelja}

U literaturi nailazimo na različite termine kojima se može opisati postupanje roditelja prema detetu: vaspitni stavovi, vaspitni stilovi, vaspitni postupci roditelja, stilovi roditeljstva itd. Između ovih određenja postoje izvesne razlike, a na neke od njih je ukazao Genc (1988) koji se bavi proučavanjem vaspitanja i vaspitnih dimenzija tokom poslednje tri decenije. On smatra da se odnos između ovih pojmova može prikazati pomoću hijerarhijskog modela, u kome bi na najnižem nivou bili vaspitni postupci, na srednjem vaspitni stavovi, a na najvišem vaspitna atmosfera porodice. U relevantnim istraživačkim radovima novijeg datuma, manje se sreće pojam vaspitna atmosfera porodice, uglavnom zbog teškoća u operacionalizaciji, a u ovom radu biće korišćen termin vaspitni stavovi roditelja.

Vaspitni stav počinje vrlo rano da se formira i proteže se kroz celo detinjstvo i mladost osobe (Todorović, 2005). To je relativno dosledan način ponašanja roditelja, kojima se uspostavljaju ukupni odnosi sa decom (Matejević, 2007). Iako se se promenom detetovih razvojnih potreba, vaspitni ciljevi kao i disciplinski zahtevi postepeno menjaju, emocionalni odnos koji prožima vaspitanje, u osnovi zadržava svoju postojanost (Todorović, 2005).

U radovima većine naših istraživača (Genc, 1994; Mihić, Zotović i Petrović, 2006; Kodžopeljić, Pekić i Genc, 2008) preovladava dvodimenzionalni model vaspitnih stavova. Najuticajnijim se pokazao Schaeferov model (Schaefer, 1959, prema Piorkowska-Petrović, 1991; Matejević, 2007), koji pretpostavlja postojanje dve dimenzije: afektivne i kontrolne. Afektivna dimenzija predstavlja emocionalni odnos roditelja prema detetu i ima dva ekstrema: toplo i hladno vaspitanje. Dimenzija kontrole pokazuje dozvoljenu psihičku i fizičku slobodu i samostalnost deteta, a njeni polovi su popustljivo i ograničavajuće vaspitanje (Schaefer, 1959, prema Piorkowska-Petrović, 1991; Matejević, 2007). Kombinacijom ovih ekstremnih tačaka ili polova dveju dimenzija dobijaju se četiri različita vaspitna stava: toplo-popustljiv, hladno-popustljiv, toplo-ograničavajući i hladno-ograničavajući vaspitni stav.

Roditelj čiji je vaspitni stav dominatno toplo-popustljiv, emotivno je blizak sa svojim detetom, pokazuje prihvatanje i pozitivne emocije. Dete je u takvoj atmosferi sigurno u roditeljsku ljubav i podršku, ali nije prezaštićeno. U kombinaciji sa toplim vaspitanjem, popustljivost ne mora da znači nepostojanje pravila, već njihovo prilagođavanje ličnosti i potrebama deteta (Kodžopeljić, 2009). Kako dete biva starije, njemu se dopušta veća sloboda i podstiče se njegovo osamostaljivanje. Kod toplo-ograničavajućeg vaspitnog stava roditelja ima elemenata prezaštićivanja deteta ali jasno postavljanje granica i pravila ponašanja nije usmereno na osujećivanje detetovih osnovnih potreba; važno je da se sa odrastanjem deteta adekvatno modifikuje ispoljavanje ograničavanja (Kodžopeljić, 2009). Hladnopopustljivi vaspitni stav karakteriše opšta nebriga za dete, roditelji se prema detetu ponašaju hladno i odbojno i ne izlaze u susret detetovim potrebama (Matejević, 2007). Popustljivost u kombinaciji sa hladnoćom označava nepostojanje jasnih pravila ponašanja. Hladno-ograničavajući vaspitni stav roditelja odlikuje retko 
ispoljavanje ljubavi, distanciran i hladan odnos prema detetu. Roditelji rigidno postavljaju pravila, a njihovo nepoštovanje oštro sankcionišu. Fizička i psihička sloboda deteta je sputana na različite načine (Matejević, 2007).

Diana Baumrind je 1967. godine izvršila reviziju Schaferovog (Schafer, 1959, prema Čudina-Obradović i Obradović, 2006) dvodimenzionalnog modela, zastupajući stav da je roditeljski nadzor (kontrola) najvažniji element roditeljske funkcije. Ona razlikuje tri osnovna stila roditeljstva: autoritarni, autoritativni (demokratski) i permisivni (laissez-fair). Autoritarni vaspitni stil podrazumeva visoko izraženu kontrolu od strane roditelja, njihovo strogo i nadmoćno ponašanje, dok se od dece očekuje poslušnost. Roditelj vidi poslušnost kao vrlinu i preferira kažnjavajuće, nasilne mere da bi zauzdao samovolju deteta, kada se detetove akcije ili verovanja ne podudaraju sa onim što on misli da je ispravno ponašanje. Odgovara hladno-ograničavajućem vaspitnom stavu iz Schaferovog modela (Opsenica-Kostić, 2012). Autoritativni roditelji postavljaju zahteve i jasna pravila ponašanja, objašnjavajući pri tome deci razloge primenjivanja tih pravila. Iako je roditeljski autoritet zadržan, atmosfera u porodici je emocionalno topla i demokratska, i dete zadržava osećanje pripadnosti i uvažavanja od strane roditelja. Odgovara Schaferovom toplo-ograničavajućem vaspitanju. Permisivni roditeljski stav podrazumeva topao emocionalni odnos prema deci, ali nedostaju definisana pravila ponašanja. Permisivan roditelj preterano ugađa sopstvenoj deci i nije u stanju da održi kontrolu nad njihovim ponašanjem. Ovakav odnos roditelja i dece odgovara toplo-popustljivom vaspitnom stavu iz Schaferovog modela. Kasnije je Baumrindova u svoj model vaspitnih stavova uključila i indeferentni stav, koji podrazumeva potpunu nebrigu o detetu. Dete je prepušteno samom sebi, jer mu nedostaju i pravila i toplina porodičnog doma. Prisutno je emocionalno zanemarivanje deteta kao posledica toga što su jedan (ili oba) roditelja često odsutni od kuće ili preokupirani nečim drugim - radom, siromaštvom, sticanjem dobara, alkoholizmom, razvodom ili bolešću (Opsenica-Kostić, 2012). Odgovara hladno-popustljivom vaspitnom stavu.

Bez obzira o kom shvatanju da je reč, roditeljski vaspitni stav je moguće opisati pomoću dve dimenzije: roditeljskom toplinom i roditeljskim nadzorom. U novije vreme se razlikuju dva oblika nadzora: spoljašnji ili nadzor ponašanja, i unutrašnji ili psihološki nadzor. Nadzor ponašanja odnosi se na postavljanje pravila ponašanja i dozvoljenih granica, kontroliše se i kažnjava kršenje postavljenih pravila i granica; njime se želi izbeći nepoželjno ponašanje deteta i adolescenata (Čudina-Obradović i Obradović, 2006). Psihološki nadzor nastoji da prati detetove unutrašnje doživljaje, emocije i misli, nepoželjan je i može kod adolescenta da podstakne depresiju, a ponekad i agresiju. Međusobno usklađivanje topline i podrške sa nadzorom, i to njegovim oblikom koji adolescent neće doživeti kao nametljiv, najveća je veština dobrog roditeljstva. 


\section{Interpersonalna orijentacija}

Osnovu za razumevanje pojma interpersonalne orijentacije čini sociopsihološka teorija Karen Horney (1885-1952), koju je razvila nakon odvajanja od Freuda, nezadovoljna biologističkim postavkama ortodoksne psihoanalize. Osnovni pojam njene teorije je bazična strepnja (Horney, 1966), koja predstavlja osećanje deteta da je izolovano i bespomoćno u potencijalno neprijateljskom svetu. Izvor bazične strepnje leži u dečijoj nesigurnosti, koja se naročito pojačava u nesređenim porodičnim odnosima (Horney, 1942, prema Horney, 1991). Bilo da se roditelji ponašaju dominantno ili nedosledno u odnosu prema detetu, da postavljaju neodgovarajuće zahteve pred dete, da su hladni i nemarni, uvek je kranji ishod dečija nesigurnost i strepnja. Nespokojno dete razvija različite taktike pokušavajući da se izbori sa osećanjem izdvojenosti, odbačenosti i bespomoćnosti (Horney, 1937, prema Horney, 1964, 1991). Ono može razviti neprijateljstvo i težiti osveti prema onima koji su ga odbacili ili maltretirali. Može postati preterano pokorno i poslušno da bi povratilo izgubljenu roditeljsku ljubav. Dete može pokušati da potkupi druge da ga vole, ili se može služiti pretnjama da ih primora na to; ako ne može da dobije ljubav, može težiti sticanju moći nad drugima i tako nadoknaditi osećanje bespomoćnosti. Takođe, dete može okrenuti svoju agresiju prema unutra i potcenjivati sebe, ili se može prepustiti samosažaljenju da bi pridobilo simpatije drugih.

Svaka od ovih taktika za rešavanje teškoća u odnosima sa drugim ljudima („značajnim drugim“) može se ustaliti i time preuzeti ulogu nagona ili potrebe u dinamici ličnosti. Dete se strepnji prilagođava uglavnom iracionalnim postupcima, a ako se delovanje izvora strepnje, a samim tim i strepnja, produže, prilagođavanje se javlja u vidu „neurotičnih potreba“. Horneyjeva (1942, prema Horney, 1991) ih naziva neurotičnim jer predstavljaju iracionalna rešenja problema, a nalazi da ih ima ukupno deset. Nešto kasnije Horneyjeva (Horney, 1945, prema Horney, 1966) razvrstava ovih deset neurotskih potreba u tri obuhatnije grupe: kretanje ka ljudima, kretanje od ljudi i kretanje protiv ljudi. Svaka od ovih grupa predstavlja neku bazičnu orijentaciju prema sebi i drugima i životu uopšte i upravo zbog toga se mogu objediniti pojmom „interpersonalne orijentacije“. Kada se kreće „prema ljudima“" (neurotična potreba za naklonošću i potvrđivanjem, ili za partnerom koji će preuzeti brigu o nečijem životu), dete prihvata svoju bespomoćnost i, uprkos svoje otuđenosti i strahovanja, pokušava da zadobije naklonost drugih i da se osloni na njih. Ako u porodici postoje protivne grupe, dete će se priključiti najmoćnijem licu ili grupi. Slažući se s njima, dete stiče osećanje pripadanja i podrške, a to doprinosi tome da se oseća manje slabim i izolovanim. Kada se kreće „protiv ljudi“" (neurotična potreba za moći, potreba da se iskorišćavaju drugi), dete apriori prihvata neprijateljstvo oko sebe i svesno ili nesvesno odlučuje se za borbu. Ono bezuslovno sumnja u osećanja i namere drugih prema. Delimično zbog sopstvene zaštite, a delimično zbog odmazde, ono želi da bude jače i da ih pobedi. Kada se kreće „od ljudi“ (neurotična potreba za samodovoljnošću i nezavisnošću, potreba da se svoj život ograniči na uske okvire), dete ne želi da nikome pripadne niti da 
se bori protiv nekog, već da se jednostavno drži po strani. Ono oseća da nema mnogo zajedničkog sa okolinom i da ga ona ni na koji način ne razume. Dete izgrađuje svoj sopstveni svet sa prirodom, svojim igračkama, svojim knjigama i svojim snovima. Kod svake od ove tri bazične orijentacije dominantan je po jedan od elemenata bazične anksioznosti: bespomoćnost u prvom, neprijateljstvo u drugom i izolacija u trećem.

Horneyjeva (1966) u navedenim orijentacijama nalazi podlogu za unutrašnje konflikte iako one nisu nužno inkopatibilne. Sukob nije ugrađen u prirodu ljudi već izrasta iz društvenih odnosa i uslova odrastanja, a razlika između normalnosti i neurotičarskog sukoba je u stepenu i prenaglašenosti. Drugim rečima, svi imaju sukobe, ali se oni mogu rešavati ili izbeći ako je dete odraslo u porodici gde ima sigurnosti, poverenja, ljubavi, poštovanja, trpeljivosti i topline.

\section{Istraživanje povezanosti vaspitnih stavova, karakteristika ličnosti i interpersonalne orijentacije}

Pregled novije literature pokazuje da je u našoj sredini sproveden veliki broj istraživanja vaspitnih stavova i stilova, procenjenih od strane dece, a ciljevi istraživanja su bili različiti. Istraživači su ispitivali kakva je rasprostranjenost pojedinih vaspitnih stilova (Kodžopeljić, Pekić i Genc, 2008; Matejević, 2007), da li postoje specifičnosti porodičnog funkcionisanja porodicama sa adolescentima (Matejević, 2012) ili u uslovima tranzicije (Mihić, 2005; Petrović, Mihić, Zotović i KaporStanulović, 2009), šta je kompetentno roditeljstvo danas (Matejević i Todorović, 2012), da li vaspitni stilovi doprinose samopoštovanju adolescenata (Todorović, 2004) i nasilnom ponašanju dece i mladih (Todorović i Stojiljković, 2007), kakve su relacije vaspitnih stavova roditelja i autoritarnosti dece (Kodžopeljić, Pekić i Genc, 2008) i tome slično. Kao posebno značajan problem ističemo ispitivanje povezanosti između dimenzija vaspitanja i razvoja ličnosti (Genc, 1988).

Razvoj podrazumeva stupanje u veliki broj različitih interpersonalnih relacija, čime se mreža ljudi sa kojima se ostvaruju bliski i uticajni odnosi širi od primarnih porodičnih relacija ka velikom broju drugih, specifičnih odnosa sa osobama i institucijama van porodičnog sistema (Mihić i Petrović, 2009). Nadalje će biti pomenuti nalazi koji posredno govore o povezanosti vaspitnih stavova i nekih aspekata socijalnog funkcionisanja. Grubor, Mihić, Zotović i Petrović (2009) su ispitivali povezanost vaspitnih stavova roditelja i aspekata self-koncepata na uzorku od 214 srednjoškolaca u Vojvodini. Autorski tim je utvrdio da je dominantan vaspitni stav oba roditelja toplo-popustljivi, a ovakve nalaze objašnjavaju velikom usmerenešću roditelja na decu u Vojvodini i izraženom bliskošću i zajedništvom koja karakteriše porodične odnose. Daljom analizom, utvrđeno je da su adolescenti, čiji roditelji primenjuju toplo-popustljivi vaspitni stav, zadovoljniji, istrajniji, imaju visok nivo samopoštovanja, doživljaj sopstvene kompetentnosti i nisu usamljeni, odnosno lakše stupaju u interakcije i odnose sa drugim ljudima. Potvrđeno je, takođe, da je afektivna dimenzija vaspitanja očeva (Mihić, 2012) 
značajan prediktor opšteg zadovoljstva, samopoštovanja, percipirane nekompetentnosti kod adolescenata, a afektivna dimenzija vaspitnog ponašanja majke je bolji prediktor usamljenosti kod adolescenata.

U svom istraživanju roditeljskog stila rukovođenja i socijalnog ponašanja učenika, Lacković-Grgin (2006) je utvrdila da roditeljski vaspitni stil doprinosi razvoju socijalnog ponašanja dece: ono je najrazvijenije kod dece iz porodica sa demokratskim vaspitnim stilom. S druge strane, rezultati istraživanja Majstorovića i saradnika (1999) pokazuju da hladno-ograničavajuće vaspitanje roditelja značajno doprinosi tome da se kod deteta razvija povlačenje u socijalnoj komunikaciji, nepoverenje i socijalna izolacija. Porodična klima koju karakteriše slaba afektivna razmena između deteta i roditelja kombinovana sa striktnom kontrolom detetovog ponašanja, uz zahtev da se pravila bez izuzetka poštuju, kod deteta razvija prepuštanje uticaja "jačima" i izbegavanje da se preuzima odgovornost i utapanje u masu. Autori zaključuju da ovakva vaspitna praksa pogoduje uspostavljanju konformističkog, submisivnog držanja kod adolescenata.

Istraživanje koje su sproveli Deković i saradnici (Deković, Janssens, \& van As, 2003, prema Čudina-Obradović i Obradović, 2006) je pokazalo da se asocijalno ponašanje najčešće javilo kod adolescenata čiji su roditelji primenjivali neprijateljske metode i metode prisile, strogu kontrolu i kažnjavanje, a odnosi roditelja i dece bili su obojeni sukobima i manjkom bliskosti i topline. Najbolje vaspitne rezulate postigli su roditelji koji su svom detetu dozvoljavali da donesu samostalne odluke, ali su pri tome nenametljivo nadzirali kako provode slobodno vreme i sa kim se druže.

Veći broj istraživača (Lianos, 2015; Belsky, Steinberg, \& Draper, 1991; McCrea \& Costa, 1988; Pincus \& Ruiz, 1997) bavio se proučavanjem relacija između roditeljskog ponašanja i socijalne prilagođenosti dece. Nalazi su pokazali da roditelji koji su percipirani kao emocionalno topli i prihvatajući podižu decu koja su emotivno stabilnija, ektravertnija, društvenija i saosećajnija (Aluja, del Barrio, \& Garcia, 2005). Osim toga, utvrđeno je da dečije i adolescentovo viđenje roditeljske podrške/prihvatanja pozitivno korelira sa osećanjem sopstvene vrednosti i socijalne efikasnosti (Rubin et al., 2004), kao i sa interpersonalnom komunikacijom, sposobnošću odlučivanja, vođenjem zdravog načina života i razvojem identiteta (Slicker, Picklesimer, Guzak, \& Fuller, 2005). Istraživanja Egberts i saradnika (Egberts, Prinzie, Dekovic, Haan, \& Akker, 2015) pokazuju da nema razlike u percepciji topline majki i očeva i njihove psihološke kontrole. Neke druge studije (Hall \& Bracken, 1996, prema Lianos, 2015) upućuju na to da su adolescenti, koji svoje majke percipiraju kao otvorene i tople, nedovoljno efikasni u odnosima sa drugim ljudima. Ima, takođe, istraživanja koja ukazuju na nejednaku ulogu vaspitnih postupaka majki i očeva u formiranju nekih osobina dece. Tako je, u jednoj kineskoj studiji (Chen, Liu, \& Li, 2000, prema Lianos, 2015), percipirana toplina očeva bila značajan prediktor društvenog i školskog uspeha, dok je majčina toplina bila prediktor emocionalne kompetentnosti.

Sumirajući empirijske nalaze uočili smo da postoje neki slični obrasci povezanosti vaspitnih postupaka roditelja i ponašanja dece, ali i da svi nalazi nisu 
međusobno konzistentni. Osim toga, imali smo u vidu da deo empirijske evidencije potiče iz proučavanja roditeljske vaspitne prakse u sredinama koje se prilično razlikuju od našeg socijalnog miljea. Takođe, u pregledanoj literaturi nismo našli konkretne podatke o povezanosti načina odgajanja dece i njihove bazične interpersonalne orijentacije, određene kao „kretanje ka ljudima“, „od ljudi“ i „protiv ljudi“ (prema shvatanju Karen Horney). Iz navedenih razloga, osmišljeno je istraživanje čiji je osnovni cilj bio da se ispitaju relacije između percipiranih roditeljskih vaspitnih postupaka i interpersonalne orijentacije mladih. Preciznije, problem istraživanja je bio da se ispita u kojoj meri se na osnovu vaspitnih stavova roditelja može predvideti filantropska i mizantropska interpersonalna orijentacija studenata. Sticanje boljeg uvida u relacije pomenutih varijabli predstavlja jedan od doprinosa istraživanja s obzirom da dosadašnja istraživanja nisu dala jasan i nedvosmislen odgovor.

\section{Metod}

\section{Uzorak i postupak}

Istraživanje je sprovedeno na prigodnom uzorku od 238 studenata (112 ispitanika muškog i 126 ženskog pola), uzrasta $18-25$ godina $(A S=21.61, S D=1.68)$. Ispitivanje je bilo anonimno, sprovedeno je tokom aprila i maja 2014. godine na Filozofskom fakultetu, Prirodno-matematičkom fakultetu i Fakultetu tehničkih nauka Univerziteta u Prištini sa privremenim sedištem u Kosovskoj Mitrovici, nakon dobrovoljnog pristanka studenata da učestvuju (prethodno im je objašnjen cilj istraživanja i rečeno da će prikupljeni podaci biti korišćeni samo u istraživačke svrhe).

\section{Instrumenti}

Skala za procenu vaspitnih stavova (VS-skala: Kodžopeljić, 2009). Namenjena je merenju vaspitnih stavova roditelja percipiranih od strane njihove dece. Nastala je kao rezultat modifikacije više ranijih instrumenata, ima dobre metrijske karakteristike, a faktorska struktura odražava dve glavne dimenzije vaspitanja (Kodžopeljić, 2009): afektivnu (toplo-hladno vaspitanje) i dimenziju kontrole (popustljivo-ograničavajuće vaspitanje). Skala je Likertovog tipa, petostepena i sadrži po 44 ajtema za oca i majku, odnosno po 11 ajtema za svaku subskalu. Pouzdanost skala na našem uzorku je na nivou koji se smatra prihvatljivim za istraživačke svrhe (Cronbachovi koeficijenti pouzdanosti: toplo vaspitanje oca i majke .77 i .78; hladno vaspitanje oca i majke .82 i .69; popustljivo vaspitanje oca i majke .75 i .59; ograničavajuće vaspitanje oca i majke .81 i .69).

Skala interpersonalne orijentacije (IO: Bezinović, 2002). Namenjena je merenju stavova prema generalizovanim drugima, pri čemu taj stav može biti pozitivan, prihvatajući, prožet poverenjem, ili pak, negativan, odbacujući i distanci- 
ran. Skala je Likertovog tipa, petostepena i sadrži 29 ajtema, raspoređenih u 4 subskale: potreba za ljudima ( 8 ajtema) i prijateljstvo ( 7 ajtema) kao mere filantropske, pozitivne orijentacije, nepoverenje ( 7 ajtema) i socijalna izolacija (6 ajtema) - kao mere mizantropske, negativne orijentacije. Shodno teorijskoj osnovi skale, koju čini shvatanje Karen Horney (1966) i Sullivana (1953), potreba za ljudima i prijateljstvo ukazuju na orijentaciju „ka ljudima”, nepoverenje ukazuje na orijentaciju „protiv ljudi”, a socijalna izolacija na orijentaciju „od ljudi”. Cronbachovi koeficijenti pouzdanosti iznose: potreba za ljudima $\alpha=.74$; prijateljstvo $\alpha=.71$; nepoverenje $\alpha=.74$ i socijalna izolacija $\alpha=.73$; filantropska orijentacija $\alpha=.84$; mizantropska orijentacija $\alpha=2.84$.

\section{Rezultati}

\section{Povezanost percipiranih vaspitnih stavova roditelja sa interpersonalnom orijentacijom studenata}

Dobijeni rezultati pokazuju da je povezanost varijabli procene roditeljskog vaspitanja i interpersonalne orijentacije studenata niskog intenziteta i da popustljivo vaspitanje oba roditelja ne korelira sa interpersonalnom orijentacijom. Kad je reč o doživljaju vaspitne prakse oca, najveća je povezanost između hladnog i ograničavajućeg vaspitanja oca, s jedne strane, i socijalne izolacije i nepoverenja, aspekata mizantropske orijentacije, s druge strane (Tabela 1). Ispitanici koji svoje očeve percipiraju kao emocionalno tople pokazuju manju sklonost socijalnoj izolaciji, a ispitanici koji svoje očeve percipiraju kao hladne, pokazuju veći stepen nepoverenja prema ljudima i socijalne izolacije. Sudeći na osnovu korelacija, utvrđeno je da ispitanici koji svoje očeve percipiraju kao ograničavajuće, pokazuju izraženiju potrebu za ljudima, ali su takođe skloni i nepoverenju u ljude i socijalnoj izolaciji.

Tabela 1

Povezanost vaspitnih stavova oca sa interpersonalnom orijentacijom studenata (Pearsonov koeficijent korelacije)

\begin{tabular}{lcccc}
\hline & $\begin{array}{c}\text { Potreba za } \\
\text { ljudima }\end{array}$ & Prijateljstvo & Nepoverenje & $\begin{array}{c}\text { Socijalna } \\
\text { izolacija }\end{array}$ \\
\hline Toplo vaspitanje oca & .04 & .07 & -.04 & $-.13^{*}$ \\
Hladno vaspitanje oca & .08 & -.03 & $.25^{* *}$ & $.30^{* *}$ \\
Popustljivo vaspitanje oca & -.02 & .03 & .04 & -.06 \\
Ograničavajuće vaspitanje oca & $.18^{* *}$ & .09 & $.23^{* *}$ & $.28^{* *}$ \\
\hline$* * p<.01 .^{*} p<.05$. & & & &
\end{tabular}

Tabela 2 pokazuje da je nađena pozitivna korelacija toplog vaspitanja majke sa prijateljstvom (kretanje ka ljudima), kao i negativna korelacija sa nepoverenjem i socijalnom izolacijom (kretanje protiv i od ljudi). Hladno vaspitanje majke pozitivno korelira sa oba aspekta mizantropske orijentacije (kao i očevo). 
Uporedivši podatke o povezanosti afektivne dimenzije vaspitanja sa interpersonalnom orijentacijom, može se primetiti da je slika o povezanosti procenjene majčine i očeve topline sa interpersonalnom orijentacijom donekle različita: odsustvo majčine topline doprinosi pojavi nepoverenja i okretanju od ljudi kod ispitanika, dok odsustvo očeve emocionalne topline neznatno doprinosi samo pojavi socijalne izolacije. Dalje, utvrđena je pozitivna korelacija ograničavajućeg vaspitanja majke sa svim aspektima interpersonalne orijentacije. Dakle, afektivna dimenzija vaspitanja majke korelira sa mizantropskom orijentacijom studenata, a negativni pol dimenzije kontrole pokazao se kao korelat obeju interpersonalnih orijentacija.

Tabela 2

Povezanost vaspitnih stavova majke sa interpersonalnom orijentacijom studenata

\begin{tabular}{lcccc}
\hline & $\begin{array}{c}\text { Potreba za } \\
\text { ljudima }\end{array}$ & Prijateljstvo & Nepoverenje & $\begin{array}{c}\text { Socijalna } \\
\text { izolacija }\end{array}$ \\
\hline Toplo vaspitanje majke & .06 & $.19^{* *}$ & $-.13^{*}$ & $-.24^{* *}$ \\
Hladno vaspitanje majke & .04 & -.06 & $.31^{* *}$ & $.33^{* *}$ \\
$\begin{array}{l}\text { Popustljivo vaspitanje majke } \\
\begin{array}{l}\text { Ograničavajuće vaspitanje } \\
\text { majke }\end{array}\end{array}$ & -.01 & .11 & .02 & -.07 \\
\hline
\end{tabular}

${ }^{* *} p<.01{ }^{*} p<.05$.

\section{Vaspitni stavovi roditelja kao prediktori filantropske i mizantropske orijentacije studenata}

Za procenu prediktivne moći vaspitnih stavova roditelja u predviđanju interpersonalne orijentacije studenata korišćen je model multiple regresije (enter postupak). Kao prediktori su uključeni modaliteti vaspitnih stavova roditelja, a pojedini aspekti filantropske i mizantropske interpersonalne orijentacije tretirani su kao kriterijumske varijable. Imajući u vidu rezultate korelacione analize, izostavljeno je popustljivo vaspitanje, a u regresioni model su uključeni ostali vaspitni stavovi roditelja.

Potreba za ljudima. Rezultati multiple regresione analize pokazuju da su dimenzije vaspitanja oca i majke značajni prediktori potrebe za ljudima i da objašnjavaju $5 \%$ varijanse ovog aspekta filantropske orijentacije $\left(R=.22, R^{2}=\right.$ $.05, F(2,235)=6.11, p=.003)$. U modelu izdvojenog skupa prediktorskih varijabli (Tabela 3) utvrđeno je da samo ograničavajući vaspitni stav majke značajno doprinosi predviđanju potrebe za ljudima kod ispitanih studenata: ispitanici koji svoje majke percipiraju kao ograničavajuće pokazuju veću potrebu za ljudima. 
Tabela 3

Vaspitni stavova oca i majke kao prediktori potrebe za ljudima - mere doprinosa pojedinačnih prediktora

\begin{tabular}{lccc}
\hline Prediktor & $\beta$ & $t$ & $p$ \\
\hline Ograničavajuće vaspitanje oca & .01 & 0.05 & .957 \\
Ograničavajuće vaspitanje majke & .22 & 2.04 & .042 \\
\hline
\end{tabular}

Prijateljstvo. Regresioni model u kome su vaspitni stavovi oba roditelja prediktori potrebe za ljudima pokazao se statistički značajnim i njime je objašnjeno $8 \%$ varijanse ovog aspekta filantropske orijentacije $\left(R=.29, R^{2}=.08, F(2,235)=\right.$ $10.40, p<.000$ ). Kad je reč o doprinosu pojedinačnih varijabli predikciji kriterijuma, jedino se vaspitni stavovi majke izdvajaju kao značajni prediktori prijateljstva (Tabela 4). Pritom, i emocionalno topli i ograničavajući vaspitni stavovi majke imaju jednako značajan doprinos u predviđanju potrebe za prijateljstvom, a smer doprinosa je pozitivan.

Tabela 4

Vaspitni stavovi oca i majke kao prediktori prijateljstva - mere doprinosa pojedinačnih prediktora

\begin{tabular}{lccc}
\hline Prediktor & $\beta$ & $t$ & $p$ \\
\hline Toplo vaspitanje majke & .27 & 4.03 & .000 \\
Ograničavajuće vaspitanje majke & .25 & 3.38 & .001 \\
\hline
\end{tabular}

Nepoverenje. Model u kome su vaspitni stavovi roditelja tretirani kao prediktori nepoverenja kao aspekta mizantropske orijentacije studenata je statistički značajan $\left(R=.33, R^{2}=.11, F(2,232)=5.71, p<.000\right)$ i njime je objašnjeno $11 \%$ varijanse nepoverenja. Iz modela prediktorskih varijabli izdvaja se jedino hladno vaspitanje majke ( $\beta=.28, p=.002)$ kao značajno u predviđanju nepoverenja (Tabela 5), iz čega sledi da su ispitanici, koji svoje majke percipiraju kao emocionalno hladne, skloni nepoverenju u interpersonalnim odnosima.

Tabela 5

Vaspitni stavovi oca i majke kao prediktori nepoverenja - mere doprinosa pojedinačnih prediktora

\begin{tabular}{lccc}
\hline Prediktor & $\beta$ & $t$ & $p$ \\
\hline Hladno vaspitanje oca & .04 & 0.42 & .675 \\
Ograničavajuće vaspitanje oca & .17 & 1.49 & .137 \\
Toplo vaspitanje majke & .03 & 0.43 & .667 \\
Hladno vaspitanje majke & .28 & 3.13 & .002 \\
Ograničavajuće vaspitanje majke & -.11 & -0.99 & .321 \\
\hline
\end{tabular}


Socijalna izolacija. Rezultati multiple regresione analize pokazuju da su dimenzije vaspitanja oca i majke značajni prediktori socijalne izolacije $(R=.39$, $\left.R^{2}=.15, F(6,231)=6.86, p<.000\right)$, i da objašnjavaju $15 \%$ varijanse ovog aspekta mizantropske orijentacije. Iz grupe prediktorskih varijabli izdvaja se samo toplo vaspitanje majke kao značajno u predviđanju socijalne izolacije (Tabela 6). Imajući u vidu negativan predznak $\beta$ koeficijenta, zaključujemo da ispitanici koji svoje majke percipiraju kao manje tople u vaspitanju pokazuju sklonost ka višem stepenu socijalne izolacije.

Tabela 6

Vaspitni stavovi oca i majke kao prediktori socijalne izolacije - mere doprinosa pojedinačnih prediktora

\begin{tabular}{lccc}
\hline Prediktor & $\beta$ & $\mathrm{t}$ & $p$ \\
\hline Toplo vaspitanje oca & .18 & 1.81 & .072 \\
Hladno vaspitanje oca & .16 & 1.45 & .148 \\
Ograničavajuće vaspitanje oca & .11 & 1.89 & .060 \\
Toplo vaspitanje majke & -.19 & -2.15 & .033 \\
Hladno vaspitanje majke & .14 & 1.50 & .134 \\
Ograničavajuće vaspitanje majke & -.11 & -0.99 & .319 \\
\hline
\end{tabular}

\section{Diskusija}

Polazna pretpostavka sprovedenog istraživanja bila je da su vaspitni stavovi roditelja značajni prediktori i filantropske i mizantropske orijentacije interpersonalne orijentacije. Nadalje su data moguća tumačenja nalaza u svetlu postojeće empirijske evidencije i teorijskog određenja ovih složenih koncepata.

Utvrđeno je da je percipirano ograničavajuće vaspitanje majke značajan prediktor potrebe za ljudima kao aspekta filantropske orijentacije. Ovakav nalaz može biti rezultat pokušaja ispitanika da traženjem podrške i saveta od vršnjaka kompenzuju nezadovoljstvo odnosom sa roditeljima. Slične nalaze saopštavaju i drugi autori (Fuligni \& Eccles, 1993; Berndt, 1979, oba prema Petrović, 2006). Takođe, percipirano toplo-ograničavajuće vaspitanje majke predstavlja značajan prediktor potrebe za prijateljstvom. Kao što je prethodno navedeno, toplo-ograničavajući vaspitni stav po Schaferu i autoritativni vaspitni stav po Baumrindovoj su vrlo slični (Matejević, 2007; Kodžopeljić i sar., 2008), a poznato je da ovakva vaspitna praksa roditelja doprinosi razvoju i formiranju energičnog, prijateljski naklonjenog, samopouzdanog i bodrog deteta usmerenog ka postignuću (Mitić, 2011). Takođe, utvđeno je da je emocionalno distancirano hladno vaspitanje majke značajan prediktor nepoverenja, a da toplo vaspitanje majke doprinosi manjoj sklonosti ispitanika ka socijalnoj izolaciji, a reč je o aspektima mizantropske orijentacije. Ovaj nalaz u saglasnosti je sa rezultatima većeg broja istraživanja, 
sprovedenih kako u našoj tako i u drugim sredinama, a nadalje će biti pomenuti samo neki. Nepovoljna porodična klima se u istraživanjima izdvaja i kao korelat pojave problema u ponašanju. Česti konflikti, kao karakteristika porodičnog okruženja, navode se kao faktor razvoja problema u ponašanju, kao i anksioznosti u socijalnim kontaktima (Mc Hale et al., 2000, prema Mihić, Zotović i Jerković, 2006). Hladni i emocionalno distancirani roditelji doprinose tome da se dete oseća usamljeno i povučeno (Mitić, 2011), da bude neprijateljski raspoloženo prema svom socijalnom okruženju, sklono konfliktima, nesretno i nestabilno (Matejević, 2007), da se kod deteta razvije povlačenje u socijalnoj komunikaciji, nepoverenje i socijalna izolacija (Majstorović i sar., 1999; Matejević, 2007), kao i nezadovoljstvo sobom (Kodžopeljić i sar., 2008). Mnoga ranija istraživanja (Pejović, 1982) ukazuju da u porodicama sa represivnim odnosom prema deci, u kojima se zahteva apsolutna poslušnost, deca često razvijaju osobine submisivnosti, zavisnosti i nedostatka inicijative.

Iako je multipla regresiona analiza pokazala da procenjena vaspitna praksa oba roditelja značajno doprinosi predikciji pojedinih modaliteta interpersonalne orijentacije ispitanika, uvidom u doprinos pojedinačnih varijabli došlo se do zaključka da su jedino vaspitni stavovi majki značajni prediktori interpersonalne orijentacije ispitanika. Ovo smatramo rezultatom vrednim pažnje, iako odstupa od naše polazne hipoteze. Pritom je afektivna dimenzija vaspitanja majke dosledno značajan prediktor interpersonalne orijentacije „kretanje od ljudi“ i „protiv ljudi“, a doprinosi i prijateljstvu kao predstavniku „kretanja ka ljudima“. S druge strane, dimenzija kontrole se pokazala kao manje značajan prediktor interpersonalne orijentacije ispitanika: popustljivo vaspitanje nije od značaja, a ograničavajuće vaspitanje majke doprinosi predviđanju oba aspekta filantropske orijentacije. Iz poslednje navedenog sledi da je (previše) kontrolišuća majka ta koja može izazvati veću potrebu za prijateljima i sklonost okretanju drugim ljudima van porodičnog okruženja, moguće kao rezultat potrebe mlade osobe za slobodom i uspostavljenjem sopstvenog identiteta. Imajući u vidu da je majka osoba koja se tradicionalno brine o kući i deci (Mihić, Zotović i Petrović, 2006), osoba koja ima najveći uticaj na društveni, emotivni i socijalni razvoj dece, moguće je razumeti zašto je njen doprinos formiranju određene interpersonalne orijentacije kod ispitanika tako važan.

U istraživanjima novijeg datuma u našoj sredini otac je, u poređenju sa ulogom majke, dosledno opisivan kao manje funkcionalan u svojoj roditeljskoj funkciji, bilo da se kvalitet relacije roditelj-dete opisuje preko vaspitnih stavova, dimenzijama pozitivne i negativne razmene, ili percipiranom brigom i zaštitom (Grubor i sar., 2008; Mihić i Petrović, 2009). Uticaj oca na razvoj deteta je specifičan i neretko drugačiji i manje vidljiv od uticaja koji ima majka, pokazuju najnovija istraživanja (Mihić, 2012). Uloga pola roditelja u odnosima između adolescentskog socijalnog prilagođavanja i roditeljske podrše/kontrole je istaknuta kao važna varijabla u novijim studijama (Lianos, 2015). Adolescenti koji izveštavaju o visokom nivou podrške, a niskom nivou rigidne kontrole od strane majke, pokazuju visok nivo socijalne kompetencije i samopoštovanja. S druge strane, Slicker i 
saradnici (Slicker et al., 2005) izveštavaju o tome da adolescenti koji svoje majke percipiraju kao prihvatajući (negujuće), a istovremeno i zahtevne, pokazuju najbolje rezultate u međuljudskim odnosima i prosocijalnom ponašanju. Iz ugla ovog nalaza valja sagledati već komentarisan nalaz našeg istraživanja o tome da su studenti koji svoje majke doživljavaju kao manje tople skloniji okretanju od drugih ljudi i socijalnoj izolaciji.

Nalaze istraživanja treba sagledati iz još jednog ugla s obzirom na to da uzorak čine studenti koji žive ili gravitiraju fakultetu u Kosovskoj Mitrovici. Novija istraživanja (Milovanović, 2014; Zlatanović, 2012) potvrđuju da je na Kosovu i Metohiji i dalje dominantna patrijarhalna kultura. Patrijarhalna kultura podrazumeva poseban način privređivanja, određenu društvenu organizaciju prilagođenu specifičnom načinu života i posebnu ideologiju i sistem vrednosti (Trebješanin, 2008). Važna odlika ovakvog kulturalnog obrasca je bitna razlika u odnosu majke prema deci, s jedne strane, i odnosa oca i dece, s druge strane. Za razliku od oca koji zastupa načelo rada, discipline i strogosti, ozbiljan je i rezervisan prema deci, majka je brižna, puna razumevanja, pa budući da se više brine o deci, majka više i utiče na njihov razvoj (Trebješanin, 2008) što govori u prilog rezultatima našeg istraživanja o većem doprinosu vaspitnih stavova majke formiranju interpersonalne orijentacije studenata.

U svetlu navedenih podataka o karakteristikama tradicionalno organizovane porodice iz kojih potiču ispitanici obuhvaćeni istraživanjem, treba dodati još nešto radi boljeg razumevanja nalaza. Iako je uloga majke da brine i neguje, od nje se takođe očekuje da "dobro vaspita decu" i otud mora uspostavljati granice, stavljati zabrane, kontrolisati decu, a time se delimično može objasniti uloga kontrolišuće dimenzije vaspitanja u oblikovanju interpersonalne orijentacije ispitanih studenata. Živeći u ograničenom i često nesigurnom socijalnom miljeu, koje nije dovoljno u stanju da zadovolji bazične potrebe za sigurnošću, prirodno je okretanje ka drugim ljudima koji su u sličnom položaju. Saglasno rečenom, treba shvatiti i podatak da je preovlađujuća vaspitna praksa, prema proceni ispitanika, hladnoograničavajuće vaspitanje i da je filantropska orijentacija dominantnije zastupljena od mizantropske (Prilog A). Ipak, procenu adolescenata da su vaspitni postupci njihovih roditelja ograničavajući i emocionalno hladni treba uzeti s rezervom $\mathrm{s}$ obzirom na to da su u periodu razvoja koji karakteriše pobuna protiv autoriteta, intenzivna potreba za oblikovanjem sopstvenog ličnog identiteta i osećaja da su jedinstveni, što je ponekad udruženo sa žestokim oponiranjem svemu što odrasli smatraju vrednim, i može dovesti do krize identiteta i zbrke uloga (Todorović, 2005).

\section{Zaključak}

Generalno gledano, dobijeni rezultati upućuju na sledeće zaključke. Percipirani vaspitni stil majke značajniji je nego vaspitni stil oca za objašnjenje interpersonalne orijentacije mlade osobe, a pritom je veći doprinos afektivne di- 
menzije vaspitanja nego dimenzije kontrole. Nalazi takođe pokazuju da su vaspitni stavovi majke bolji prediktori mizantropske nego filantropske orijentacije na ispitanom uzorku studenata, a smatramo pozitivnim to što je okrenutost ka ljudima dominantnija od orijentacije od ili protiv ljudi. S obzirom na to da je mali procenat varijanse kriterijuma objašnjen uz pomoć prediktorskih varijabli, naredna istraživanja bi trebalo da obuhvate širi opseg potencijalnih prediktora. Preporuka bi bila uključivanje varijabli ličnosti, vrednosnih orijentacija, zatim karakteristika socio-političkog konteksta odrastanja, religioznosti (kao važne odrednice socijalnog identiteta, naročito u multikulturalnim sredinama), a sve zbog toga što vaspitni stavovi roditelja ne deluju nezavisno od šireg društvenog konteksta. U svakom slučaju, sprovedeno istraživanje predstavlja korak napred u sagledavanju složenih relacija između roditeljske vaspitne prakse i interpersonalne orijentacije mladih iako su neka pitanja i dalje otvorena.

Jedno od ograničenja istraživanja tiče se karakteristika primenjenih instrumenata. Reč je o upitniku za procenu vaspitnih stavova roditelja koji podrazumeva subjektivnu procenu vaspitnih stavova roditelja od strane njihove dece. Ovo znači da procena može biti donekle iskrivljena zbog upliva drugih činioca koji proističu iz trenutnih nesporazuma s roditeljima, ili previše kritična i nedovoljno utemeljena u realnosti zbog potrebe osobe adolescentnog uzrasta za separacijom i individuacijom. Preporuka za naredna istraživanja bi bila primena i drugih tehnika koje bi se zasnivale na samoproceni roditelja ili bi podrazumevale procenu vaspitnog stava roditelja istovremeno od strane deteta i roditelja. Druga grupa ograničenja tiče se uzorka. Uzorak je prigodan i ovim istraživanjem su obuhvaćene samo porodice sa decom adolescentnog uzrasta, a buduća istraživanja bi trebalo usmeriti na ispitavanje funkcionisanja porodice sa decom mlađeg uzrasta (predškolskog i osnovnoškolskog).

Sticanje boljeg uvida u način povezanosti ispitivanih varijabli predstavlja jedan od teorijskih doprinosa istraživanja, ali dobijeni nalazi imaju i svoje praktične implikacije. S obzirom na sliku o dominantno prisutnom vaspitnom stilu (nezavisno od stepena objektivnosti procene ispitanika), valjalo bi raditi na poboljšanju odnosa roditelj-dete. Čini se da je potreban kontinuiran edukativni rad naročito na relaciji dete-otac, jer u nekim sredinama otac i dalje ne učestvuje dovoljno $u$ vaspitanju (Mihić, 2010). Korisno bi bilo organizovanje neke vrste „škole roditeljstva” u formi seminara i radionica, na kojima bi se konkretno prorađivali problemi roditelja i dece, odlike razvojnih perioda i aktuelnih „zadataka” članova porodice (na primer, kako se pripremiti za vrtić, za polazak u školu, mogućnosti i izazovi adolescencije itd). Porodica za dete treba da predstavlja sigurnu bazu, a kao oblik društvene podrške, porodica pomaže u prevazilaženju stresa (Todorović, 2005). Da bi porodica bila optimalna sredina za razvoj deteta, neophodno je da između roditelja i deteta postoji adekvatna emocionalna razmena, dobra i otvorena komunikacija, kao i odgovarajuća raspodela uloga (Matejević i Todorović, 2012). Za poboljšanje odnosa između roditelja i deteta preporučuje se edukacija samih roditelja o kvalitetnijim vaspitnim postupcima. Matejević i Todorović (2012) navode niz programa grupnog obrazovanja roditelja koji se teorijski baziraju na modelu 
autoritativnog roditeljstva Baumrindove, na vežbama efektivne komunikacije i na principima promene ponašanja. U tom smislu ima prostora za angažman psihološko-pedagoških savetovališta, čime bi se osvestili pojedini aspekti roditeljstva i pozicije deteta i tako pomoglo obema stranama u vaspitnom procesu da se bolje razumeju.

\section{Reference}

Aluja, A., del Barrio, V., \& Garcia, L.F. (2005). Relationships between adolescents' memory of parental rearing styles, social values, and socialization behavior traits. Personality and Individual Differences, 39, 903-912. doi:10.1016/j. paid.2005.02.028

Belsky, J., Steinberg, L., \& Draper, P. (1991). Childhood experience, interpersonal development, and reproductive strategy: An evolutionary theory of socialization. Child Development, 62, 647-670. doi:10.2307/1131166

Bezinović, P. (2002). Skala interpersonalne orijentacije - IO. U K. Lacković-Grgin, A. Proroković, V. Ćubela i Z. Penezić (Ur.), Zbirka psihologijskih skala i upitnika. Svezak 1 (str. 69-72). Zadar: Filozofski fakultet.

Čudina-Obradović, M. i Obradović, J. (2006). Psihologija braka i obitelji. Zagreb: Golden marketing - Tehnička knjiga.

Egberts, M. R., Prinzie, P., Dekovic, M., de Haan, M. D., \& van den Akker, A. L. (2015). The prospective relationship between child personality and perceived parenting: Mediation by parental sense of competence. Personality and Individual Differences, 77, 193-198. doi:10.1016/j.paid.2014.12.046

Genc, L. (1988). Dimenzije vaspitanja i razvoj ličnosti: teorija i istraživanja. Psihologija, 21, 121-132.

Genc, L. (1994). Percepcija zastupljenosti vaspitnih postupaka roditelja u zavisnosti od pola, uzrasta, socioekonomskog statusa i školskog uspeha adolescenata. U Đ. Đurić (Ur.), Ličnost u višekulturnoj sredini (str. 15-24). Novi Sad: Filozofski fakultet, Odsek za psihologiju.

Grubor, S., Mihić, I., Zotović, M. i Petrović, J. (2009). Relacije self koncepta adolescenata i procenjenih vaspitnih stilova njihovih roditelja. Pedagoška stvarnost $L V, 5-6,622-635$.

Horney, K. (1964). Neurotična ličnost našeg doba. Titograd: Grafički zavod.

Horney, K. (1966). Naši unutrašnji konflikti. Titograd: Grafički zavod.

Horney, K. (1991). Neurotična ličnost našeg doba. Beograd: Vojislav Milić MOND.

Kodžopeljić, J. (2009). Procena vaspitnih stavova (VS-skala). U M. Biro, S. Smederevac i Z. Novović (Ur.), Procena psiholoških i psihopatoloških fenomena (str. 165-178). Beograd: Centar za primenjenu psihologiju.

Kodžopeljić, J., Pekić, J. i Genc, A. (2008). Relacije između vaspitnih stavova roditelja i autoritarnosti dece. Pedagoška stvarnost, LIV, 9-10, 1027-1038.

Lacković-Grgin, K. (2006). Psihologija adolescencije. Jastrebarsko: Naklada Slap. 
Lianos, P. G. (2015). Parenting and social competence in school: The role of preadolescents' personality traits. Journal of Adolescence, 41, 109-120. doi:10.1016/j.adolescence.2015.03.006

Majstorović, N., Kodžopeljić, J. i Mirković, S. (1999). Povezanost vaspitnih stavova roditelja i konformizma njihove dece. Pedagoška stvarnost, MCXCIX, 1-2, 109-123.

Matejević, M. (2007). Vrednosne orijentacije i vaspitni stil roditelja. Niš: Filozofski fakultet.

Matejević, M. (2012). Funkcionalnost porodičnih sistema i vaspitni stil roditelja i obrasci komunikacije u porodicama sa adolescentima. Nastava i vaspitanje, LXI, 1, 128-141.

Matejević, M. i Todorović, J. (2012). Funkcionalnost porodičnih odnosa i kompetentno roditeljstvo. Niš: Filozofski fakultet.

McCrae, R. R., \& Costa, P. T. (1988). Recalled parent-child relations and adult personality. Journal of Personality, 56, 417-434. doi:10.1111/j.1467-6494.1988. tb00894.x

Mihić, I. (2005). Uloga vaspitnog stila roditelja u proceni porodice. U M. Franceško i M. Zotović (Ur.) Psihosocijalni aspekti društvene tranzicije u Srbiji (str. 238-254). Univerzitet u Novom Sadu, Filozofski fakultet.

Mihić, I. (2010). Uključenost oca u brigu o detetu: efekti očevih iskustava iz porodice porekla i kvaliteta relacija u porodici prokreacije. Primenjena psihologija, 3, 197-222.

Mihić, I. (2012). Modelovanje roditeljske uloge oca: iskustvo u porodici porekla i uključenost oca. Zbornik Instituta za pedagoška istraživanja, 44, 332-348.

Mihić, I. i Petrović, J. (2009). Percepcija kvaliteta odnosa unutar porodice - iskustvo adolescenata iz Srbije. Primenjena psihologija, 2, 369-384.

Mihić, I., Zotović, M. i Jerković, I. (2006). Struktura i sociodemografski korelati porodične klime u Vojvodini. Psihologija, 39, 297-312.

Mihić, I., Zotović, M. i Petrović, J. (2006). Sociodemografske karakteristike porodice, podela posla u kući i vaspitni stilovi roditelja u porodicama na teritoriji Vojvodini. Pedagoška stvarnost, LII, 1-2, 118-134.

Milovanović, I. (2014). Uticaj postkonfliktnih društvenih promena na svakodnevni život žena na Kosovu i Metohiji - mogućnosti primene metode slučaja (Nepublikovana doktorska disertacija). Filozofski fakultet, Univerzitet $\mathrm{u}$ Novom Sadu, Novi Sad.

Mitić, M. (2011). Deca sa smetnjama u razvoju, potreba i podrška. Beograd: Republički zavod za socijalnu zaštitu.

Opsenica-Kostić, J. (2012). Adolescenti i njihovi roditelji u svetlu PART teorije (Nepublikovana doktorska disertacija). Univerzitet u Nišu, Filozofski fakultet. Pejović, M. (1982). Interpersonalni odnosi i porodica. Avalske sveske, 5/82, 27-39. Petrović, J. (2006). Percepcija kvaliteta socijalnih odnosa u adolescenciji. Teme, 30/2, 291-305. 
Petrović, J., Mihić, I., Zotović, M. i Kapor-Stanulović, N. (2009). Porodične uloge oca i majke u porodicama u procesu tranzicije. Zbornik Matice srpske za društvene nauke, 128, 31-46.

Pincus, A. L., \& Ruiz, M.A. (1997). Parental representations and dimensions of personality: Empirical relations and assessment implications. Journal of Personality Assessment, 68, 436-454. doi:10.1207/s15327752jpa6802_12

Piorkowska-Petrović, K. (1991). Jedan model za ispitivanje vaspitnih stavova roditelja, Psihologija, 24, 1-2, 170-179.

Rubin, K. H., Dwyer, K. M., Booth-LaForce, C., Kim, A. H., Burgess, K. B., \& RoseKrasnor, L. (2004). Attachment, friendship, and psychosocial functioning in early adolescence. The Journal of Early Adolescence, 24, 326-356. doi:10.1177/0272431604268530

Sullivan, H. S. (1953). The interpersonal theory of psychiatry. New York: Norton.

Slicker, E. K., Picklesimer, B. K., Guzak, A. K., \& Fuller, D.K. (2005). The relationship of parenting style to older adolescent life-skills development in the United States. Young, 13, 227-245. doi:10.1177/1103308805054211

Todorović, J. (2004). Vaspitni stilovi u porodici i stabilnost samopoštovanja adolescenata. Psihologija, 37, 183-194.

Todorović, J. (2005). Vaspitni stilovi roditelja i samopoštovanje adolescenata. Niš: Prosveta.

Todorović, J. i Stojiljković, S. (2007). Porodični činioci nasilnog ponašanja dece i omladine. U N. Jovanović i Lj. Mitrović (Ur.), Omladina Balkana između nasilja i kulture mira (str. 115-129). Niš: Filozofski fakultet.

Trebješanin, Ž. (2008). Predstava o detetu u srpskoj kulturi. Beograd: Sofos.

Zlatanović, S. (2012). Odnos etničkog i drugih oblika kolektivnog identiteta: terenska istraživanja srpske zajednice na jugoistoku Kosova (Nepublikovana doktorska disertacija). Filozofski fakultet, Univerzitet u Beogradu, Beograd. 


\section{Prilog A}

Tabela A1

Sirovi i T-skorovi na skali VS - percepcija vaspitnih stavova roditelja

\begin{tabular}{llcccc}
\hline & & \multicolumn{2}{c}{ Otac } & \multicolumn{2}{c}{ Majka } \\
\hline VASPITNI STAV & & $\begin{array}{c}\text { Sirovi } \\
\text { skorovi }\end{array}$ & T-skorovi & $\begin{array}{c}\text { Sirovi } \\
\text { skorovi }\end{array}$ & T-skorovi \\
\hline Toplo vaspitanje & Muški & 43 & 47 & 45 & 48 \\
& Ženski & 45 & 48 & 48 & 47 \\
& Ukupno & 44 & $*$ & 46 & $*$ \\
Hladno vaspitanje & Muški & 25 & 56 & 24 & 59 \\
& Ženski & 23 & 56 & 20 & 56 \\
\multirow{2}{*}{ Popustljivo vaspitanje } & Ukupno & 24 & $*$ & 21 & $*$ \\
& Muški & 41 & 49 & 43 & 52 \\
Ženski & 41 & 44 & 43 & 46 \\
Ograničavajuće & Ukupno & 41 & $*$ & 41 & $*$ \\
vaspitanje & Muški & 27 & 57 & 27 & 55 \\
& Ženski & 24 & 60 & 24 & 53 \\
& Ukupno & 26 & $*$ & 27 & $*$ \\
\hline
\end{tabular}

Tabela A2

Deskriptivni pokazatelji izraženosti interpersonalne orijentacije

\begin{tabular}{lcccc}
\hline \multicolumn{1}{c}{$\begin{array}{c}\text { Interpersonalna } \\
\text { orijentacija }\end{array}$} & $N$ & $\begin{array}{c}\text { Empirijski raspon } \\
\text { skorova }\end{array}$ & $A S$ & $S D$ \\
\hline Potreba za ljudima & 238 & $4-31$ & 18.67 & 5.76 \\
Prijateljstvo & 238 & $1-28$ & 18.63 & 4.76 \\
Filantropska orijentacija & 238 & $5-59$ & 37.29 & 9.84 \\
Nepoverenje & 238 & $0-28$ & 13.08 & 5.84 \\
Socijalna izolacija & 238 & $0-42$ & 9.18 & 5.97 \\
Mizantropska orijentacija & 238 & $1-62$ & 22.26 & 10.69 \\
\hline
\end{tabular}




\section{Miljana Pavićević}

Department of

Psychology, Faculty

of Philosophy in

Kosovska Mitrovica, University of Priština

\section{Snežana Stojiljković}

\section{Department of}

Psychology, Faculty of Philosophy, University of Niš
PERCIEVED PARENTAL REARING

ATTITUDES AS PREDICTORS OF THE INTERPERSONAL ORIENTATION OF STUDENTS

Previous research has shown that parental rearing manners contribute to the formation of different personality traits and interpersonal relations that children establish during their development. The aim of this paper is to examine the predictive power of the parental rearing attitudes for the interpersonal orientation of students, more precisely, certain aspects of philanthropic and misanthropic orientation. The research was conducted on 238 students of both genders, from different faculties of the University of Priština, whose average age was 21.61. The data were gathered using the Parental Rearing Style Scale (PRS) and the Interpersonal Orientation Scale (IO). The PRS scale measures two dimensions of rearing, the affective one (warm and cold style of rearing) and the dimension of control (indulgent and restricting style of rearing). The results of the multiple regression analysis point out that the perceived warm mother's style of rearing is a significant predictor of friendship, an aspect of philanthropic orientation, and social isolation (with a negative sign), which is an aspect of misanthropic orientation. Cold mother's style of rearing is a significant predictor of mistrust, an aspect of misanthropic orientation, while the restricting rearing is a significant predictor of the need for presence of people and friendship, representing an aspect of philanthropic orientation. The father's rearing attitudes are not significant predictors of the interpersonal orientation of students. Generally speaking, the perceived mother's rearing style is more significant than the father's rearing style in explanation of the interpersonal orientation of students, where a contribution of the affective dimension of rearing is higher than a contribution of the dimension of control. The results are discussed in the light of the available empirical evidence in this field of psychology pointing to future research needs.

Keywords: parental rearing attitudes, interpersonal orientation, philanthropic orientation, misanthropic orientation, students 